\title{
Comparative Study of Water Before and After Mantra Treatment (Hindu Perspective)
}

\author{
I Nyoman Subagia, I Gusti Made Widya Sena, I Made Suta \\ \{nyomansubagia1182@gmail.com\} \\ Pascasarjana, Institut Hindu Dharma Negeri Denpasar, Indonesia
}

\begin{abstract}
This study analyzes the quality of water before and after mantra treatment (Hindu Perspective). It uses clean water from the ground, which is called kelebutan. In general, kelebutan is used as a source of drinking water and for spiritual activities among the Keramas, Blabatuh, and Gianyar communities. The study aims to determine the differences in water content, minerals, nitrogen, fluorine, phosphorus, sulfur and chlorine, as well as its efficacy for the health of the human body. It uses a quantitative approach with Gravimetri, Semimikrokjeldahl, and Soxhlet methods. The results showed that the physical quality of water in the control and treatment fulfilled the health requirements. Based on chemical parameters, there were $\mathrm{Pb}$ heavy in high levels in both the control and treatment. Microbiological water quality shows that there is an increase in the number of coliforms and total bacteria causing post-treatment contamination. The presence of components such as antioxidants in the water is attributed to the addition of flowers and mantra. In the molecular form, water forms a hexagonal structure.
\end{abstract}

Keywords: Water, Kelebutan, Mantra

\section{Pendahuluan}

Air merupakan suatu kebutuhan yan tidak dapat dipisahkan dari kehidupan manusia, karena air diperlukan untuk bermacam-macam kegiatan seperti minum, pertanian, industri, perikanan, dan rekreasi. Air meliputi $70 \%$ dari permukaan bumi, tetapi banyak negara yang persediaan air terdapat dalam jumlah yang sangat terbatas. Bukan hanya jumlahnya yang penting, tetapi juga mutu air diperlukan untuk penggunaan tertentu, seperti industri atau konsumsi. [1] mengklasifikasikan air menjadi dua jenis, yaitu: (1) air yang dipakai sebagai keperluan sehari-hari (bersifat profan), (2) air yang dipakai sebagai keperluan agama atau untuk upacara tertentu, yang disebut dengan air suci (holy water). Selanjutnya [2] juga menyatakan pada masyarakat Bali dibedakan dua jenis air yaitu, air yang dipergunakan untuk memenuhi kebutuhan hidup sehari-hari (profan) dan juga air yang digunakan untuk kebutuhan upacara agama (sakral). Dalam kitab Rg. Weda, X.17.10 disebutkan demikian: semogalah air suci ini menyucikan kami bercahaya gemerlapan. Semogalah pembersih ini membersihkan kami dengan air suci. Semoga air suci ini mengusir segala kecemaran. Sungguh kami bangkit memperoleh kesucian darinya. Keyakinan masyarakat Bali bahwa air suci akan memberikan kecemerlangan 
dan bercahaya dalam diri manusia, air suci dipercaya akan mampu mengusir segala penyakit, pencemaran hidup sehari-hari.

Mantra yang diucapkan dalam rangka pembuatan tirtha, diantaranya adalah mantra suci berikut:

Om Gangga Saraswasty Sindhu, Wipasa Kausikinadi, Jamuna Mahasrestha Serayau sa Mahanadi, Om ganggadewi Mahapunya, Gangga-sahasranedhini, Ganggataranggana-samyukte, Ganggadewi namostute, Om Gangga mahadewi tadupamamrtanjiwani, Ungkarasara bhuwana-padamrta-manohara, Om utpatika surasanca, utpati tawa ghoras-ca, Utpeti sarwa-hitan-ca, utpawiwa sriwahinam.

Terjemahan:

Hamba menuju dikau, O Gangga, Saraswati, Sindhu, Wipasa, Kausiki, Jamuna, Serayu, sungai suci yang agung, Dewi Gangga yang suci, Gangga sumber ribuan ilmu pengetahuan, yang bersatu dalam riak gelombang sungai Gangga, Dewi Gangga yang maha indah. Dikau adalah maha gaib merupakan air suci kehidupan abadi, dalam aksara suci dikau adalah aksara, $\mathrm{U}$, di dalam alam

Agama Hindu khususnya, umat Hindu di Bali, air menjadi kebutuhan yang utama tanpa disadari, dari bangun pagi, beraktivitas, berupacara, bahkan dalam kematian membutuhkan air. Air dalam penggunaannya sebagai sarana upacara, sebelumnya didoakan atau diberikan mantra yang dikenal dengan tirtha. Umat Hindu meyakini bahwa dalam tirtha terdapat sesuatu anugerah yang terkandung didalamnya, tergantung pada peruntukannya. Keyakinan ini telah menjadi suatu kepercayaan yang telah turun temurun yang diwarisi. Ternyata dibalik keyakinan tersebut, ada fenomena ilmiah yang bisa memberikan kepercayaan itu menjadi lebih kuat mengenai keajaiban dari sifat air dan keadaan air setelah diberikan perlakuan, baik didoakan, atau diberikan mantra. Oleh karena itu, dalam tulisan ini akan diulas mengenai kandungan air, mineral, nitrogen, fluor, fosfor, sulfur dan klor, serta khasiat air untuk kesehatan tubuh manusia.

Berikut ini adalah ulasan tentang penelitian yang berkaitan dengan isu penelitian saat ini. Pertama, sebuah penelitian yang dilakukan oleh [3] tentang 'pemisahan dan pengukuran ${ }^{129} \mathrm{I}$ dan ${ }^{127} \mathrm{I}$ di ganggang laut era pra-nuklir dengan rasio isotop ${ }^{129} \mathrm{I} /{ }^{127} \mathrm{I}$ yang sangat rendah'. Metode ekstraksi yodium yang dijelaskan dalam penelitian ini dapat dengan mudah dan memisahkan yodium dengan aman dari sampel alga laut dengan efisiensi pengumpulan dalam kisaran 1699\%. Ketika digunakan di lingkungan yang bebas dari udara sekitar, yang mengandung kadar ${ }^{129}$ I yang tinggi, metode ini dapat dengan mudah memisahkan isotop yodium dengan rasio ${ }^{129} \mathrm{I}$ $/{ }^{127} \mathrm{I}$ yang sangat rendah $\left(-10^{-13}-10^{-12}\right)$. Rasio ${ }^{129} \mathrm{I} /{ }^{127} \mathrm{I}$ dalam sampel alga yang dikumpulkan pada era pra-nuklir adalah $10^{-13}-10^{-12}$, sedangkan rasio diukur untuk sampel alga tahun 1987 adalah $2 \times 10^{-10}$, dengan demikian menunjukkan bahwa rasio ${ }^{129} \mathrm{I} /{ }^{127} \mathrm{Idalam}$ ganggang pasca-nuklir adalah 100-1000 kali setinggi ganggang era pra-nuklir. Peningkatan drastis pada rasio ${ }^{129} \mathrm{I} /{ }^{127} \mathrm{I}$ dalam ganggang ini disebabkan oleh aktivitas manusia. Kedua, [4] tentang 'Mobilitas Pori-air: Distribusi $\mathrm{d}^{37} \mathrm{Cl},{ }^{36} \mathrm{Cl} / \mathrm{Cl},{ }^{129} \mathrm{I} /{ }^{127} \mathrm{I}$ dan dilarutkan konsentrasi ${ }^{4} \mathrm{He}$ dalam inti yang dibor di ladang gas Mobara, Jepang'. Hasil penanggalan pori-air memiliki perbedaan yang tidak signifikan antara usia formasi Kazusa Group, dibandingkan dengan usia yodium dari rasio ${ }^{129} \mathrm{I}^{127} \mathrm{I}$. Variasi $\mathrm{d}^{37} \mathrm{Cl}$ dalam air pori menunjukkan bahwa transportasi massal dalam batuan Grup Kazusa dominan dikendalikan oleh difusi.

Selanjutnya, sebuah penelitian yang dilakukan oleh [5] tentang 'Evaluasi kapasitas penyerapan $\mathrm{CO} 2$ batu menggunakan metode gravimetri untuk penyerapan geologis $\mathrm{CO} 2$ '. Hasil penelitian [5] menunjukan bahwa di kedua Kimachi Sandstone dan Iidate Granite, ditemukan bahwa kapasitas penyerapan $\mathrm{CO}_{2}$ berkurang dengan meningkatnya suhu, dan massa baik dari batu pasir dan granit setelah pengukuran menunjukkan sedikit perubahan dalam kondisi vakum 
dibandingkan dengan sebelum pengukuran di seluruh durasi eksperimental. Oleh karena itu, disarankan bahwa perilaku penyerapan dalam sistem batuan- $\mathrm{CO}_{2}$ sangat tergantung pada sifatsifat fluida unsur $\mathrm{CO} 2$ (misalnya kepadatan, entalpi), dan kemudian tampaknya mendukung penyerapan fisik seperti yang dilaporkan untuk berbagai bahan sorben lain, yaitu, karbon aktif, batubara, polimer. Dari penelitian ini, terdapat kesamaan dalam penggunaan metode yaitu metode gravimetric, namun bedanya adalah objek penelitian yang dikaji sangat berbeda.

Terakhir, penelitian dari [6] tentang 'Simulations of the Three-Dimensional Total Dissolved Gas Saturation Downstream of Spillways Under Unsteady Conditions'. Hasil dari penelitian ini menunjukan bahwa (1) Model dinamika fluida komputasi aliran dua fase 3-D yang tidak stabil digunakan untuk memprediksi distribusi TDG. Parameter berbagai faktor termasuk kecepatan, tekanan, dan volume udara yang terperangkap yang terlibat dalam jenuh gas dimasukkan ke dalam pemodelan komputasi (2) Model ini digunakan untuk memprediksi hidrodinamika dan distribusi TDG dalam kondisi debit yang tidak stabil dengan proyek Gezhouba sebagai contoh. Kesepakatan yang baik antara data lapangan dan hasil numerik menunjukkan bahwa pembuangan bendungan akan signifikan untuk konsentrasi TDG hilir (3) Penelitian lebih lanjut harus mencakup pengaruh suhu pada model saturasi TDG. Selain itu, karena fraksi udara dan ukuran gelembung ditetapkan sebagai kondisi batas awal dalam penelitian ini, kombinasi berbagai fraksi udara dan ukuran gelembung harus diterapkan dalam pekerjaan mendatang. Dari pemaparan penelitian di atas, adapun tujuan dari penelitian yang baru ini dimaksudkan untuk mengetahui perbedaan kandungan air, mineral, nitrogen, fluor, fosfor, sulfur dan klor, serta khasiat air untuk kesehatan tubuh manusia

\section{Metode}

Penelitian ini menggunakan pendekatan kuantitatif dengan metode Gravimetri, Semimikrokjeldahl, dan Soxhlet. Gravimetri merupakan salah satu metode kimia analitik untuk menentukan kuantitas suatu zat atau komponen yang telah diketahui dengan cara mengukur berat komponen dalam keadaan murni setelah melalui proses pemisahan. Analisis gravimetri melibatkan proses isolasi dan pengukuran berat suatu unsur atau senyawa tertentu. Dalam hal ini, gravimetri digunakan dalam analisis kadar air. Air kelebutan yang digunakan sebagai sampel diperoleh dari wilayah Keramas Gianyar (Kelebutan Pakerisan), yang berlokasi di daerah ladang (pertegalan), agak jauh dari lokasi pemukiman penduduk (kira-kira 200 meter) dan dikelilingi oleh pohon-pohon besar, sehingga suasana lokasi sampel sangat sejuk dengan kualitas udara yang baik dan jauh dari pencemaran udara. Sampel air diambil menggunakan 2 botol stoples, 1 botol untuk kontrol (tanpa diberi mantra) dan satunya lagi diberikan mantra dan kembang. Sampel air diambil pada waktu sore hari jam 17.00 wita.

\section{Hasil dan Pembahasan}

\subsection{Karakteristik Fisika Sampel}


Hasil analisis karakter fisik mutu air yang dilakukan pengujian meliputi bau/ aroma, warna, dan Nilai pH (SNI 01-3553 2006).

$\begin{array}{lccc}\text { Parameter Fisik Air } & \text { Kontrol } & \text { Perlakuan } & \text { Standar Baku Air Minum } \\ \text { Bau } & \text { Tidak berbau } & \text { Beraroma kembang } & \text { Tidak berbau } \\ \text { Warna } & \text { Jernih } & \text { Jernih } & \text { Jernih } \\ \text { Rasa } & \text { Tidak berasa } & \text { Berasa kenanga } & \text { Tidak berasa } \\ \text { pH } & 7.03 & 7.00 & 6,0-8,5\end{array}$

Pengamatan karakterfisik sampel sesuai tabel diatas, bila dibandingkan dengan standar mutu air minum, maka dapat dijelaskan bahwa wujud fisik air pada perlakuan dan control memberikan persyaratan mutu air minum berdasarkan SNI 2006, sehingga secara ilmiah kriteria air pada kontrol dan perlakuan memenuhi syarat secara fisik sebagai sumber air minum. Namun secara empiris masyarakat Hindu di Bali mengkonsumsi air dari sumber mata air di pegunungan dan sekitarnya sebagai sumber air minum, dan sangat jarang terjadi insiden keracunan dari sumber mata air, dan jikapun ada umumnya bersumber dari cemaran limbah hunian perumahan karena lokasi sumber mata air dekat dengan pemukiman, ataupun cemaran residu logam berat sebagai akibat cemaran limbah pestisida dari ladang. Kualitas fisik air dari kontrol dan perlakuan memenuhi kriteria sebagai sumber air minum berdasarakan SNI mutu air minum dari departemen kesehatan.

Sedangkan pada perlakuan air dengan pemberian doa dan kembang secara fisik menunjukkan perbedaan yang jelas dari warna, bau, rasa dan $\mathrm{pH}$, mengalami perubahan secara fisik, hal ini disebabkan oleh pembarian bunga kamboja dan kenanga yang umumnya ditambahkan pada saat pembuatan air suci atau tirtha sebelum diberikan mantra-mantra. Secara sensori perubahan fisik air itu tidak menurunkan kualitas mutu karena tetap bisa dikonsumsi sebagai sumber air suci termasuk perubahan $\mathrm{pH}$ dari netral menjadi agak sedikit asam, tetapi masih masuk dalam kategori standar $\mathrm{pH}$ sebagai sumber air minum yaitu $(6,0-8,5)$. Air dengan perlakuan mantra dan pemberian kembang tidak memiliki daya simpan yang lama karena pengaruh senyawa terlarut yang menyebabkan kontaminasi pada air oleh bakteri pembusuk, mengingat air merupakan media terbaik tumbuh dan berkembangnya bakteri terutama e-coli yang berasal dari kontaminasi silang oleh udara, bakteri pada air atau oleh akibat reaksi pembususkan kembang yang terendam dalam air. Namun pada kondisi tertentu justru dengan penambahan kembang mengakibatkan air memiliki senyawa aktif terlarut yang mempunyai efek fiologis tertentu, termasuk memberikan efek penenang (sedatifa) dan pengaruh positif lainnya sehingga sering digunakan sebagai terapi kesehatan.

Akibat pengaruh pemberian mantra terhadap sifat fisik air tidak bisa teramati dengan kasat mata harus dilakukan dengan analisis kristalografi, mengamati perubahan struktur molekul dibawah mikroskop untuk melihat bentuk perubahan struktur setelah diberikan perlakuan, apakah membentuk kristal, struktur heksagonal atau bentuk yang lainnya, karena secara teoritis dan dari hasil penelitian di Jepang menyatakan bahwa air dengan perubahan struktur menjadi heksagonal mempunyai peran positif bagi efek fisiologis tubuh dibandingkan struktur air tanpa perlakuan.

\subsection{Karakteristik Kimia Sampel}

Karakteristik kimia air kelebutan yang diberikan pelakuan dan kontrol disajikan pada Tabel. Pada Tabel tersebut tampak bahwa beberapa pengujian kimia difokuskan mengacu pada kualitas kimia air minum dengan menganalisis parameter cemaran logam berat dan beberapa logam tertentu yang kemungkinnan mencemari sumber air serta beberapa perubahan terhadap kadar mineral akibat perlakuan. 
Tabel 1. Karakteristik Kimia Air Kelebutan Pakerisan Kontrol dan Perlakuan

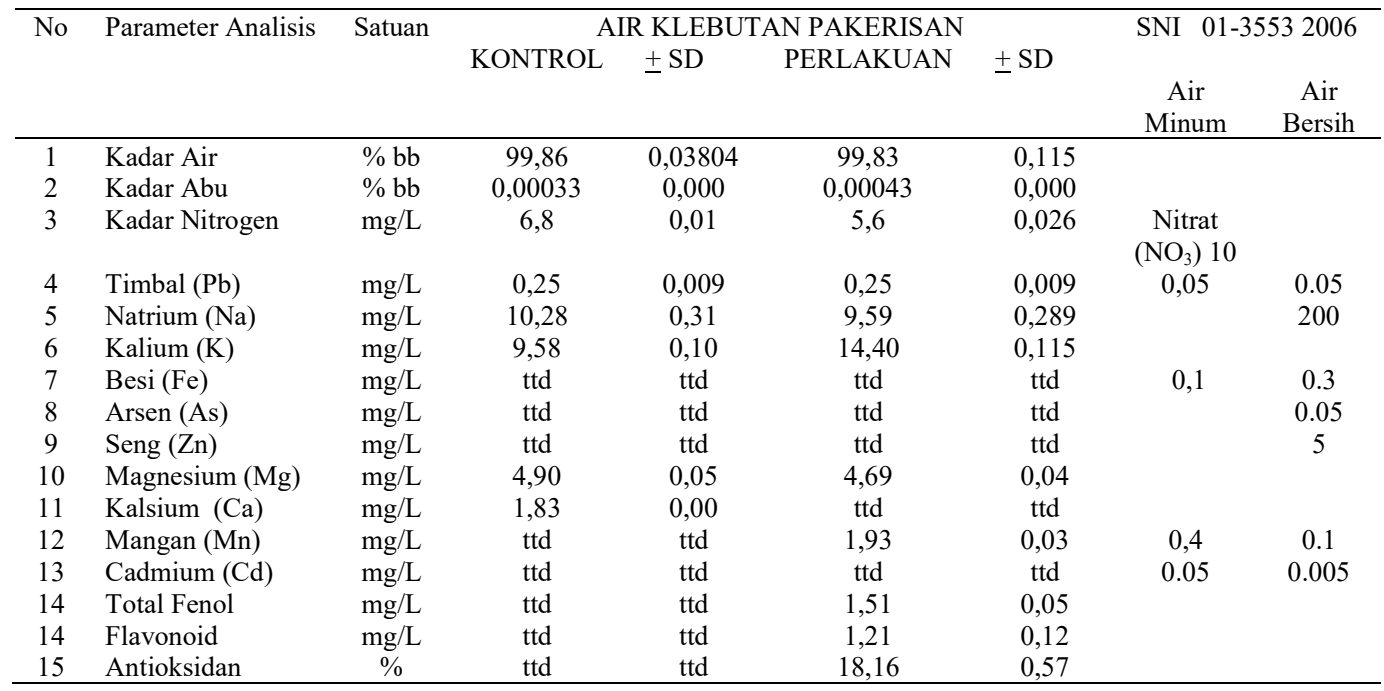

Hasil Analisis kimia menunjukkan bahwa air kelebutan pakerisan di tinjau dari kadar air tidak memperlihatkan perbedaan yang signifikan sebelum dan setelah perlakuan karena tidak banyak faktor yang mempengaruhi kadar air mengalami perubahan, dimana faktor-faktor yang mempengaruhi perubahan kadar air umumnya adalah akibat pengaruh suhu/ perlakuan pemanasan yang menurunkan kadar air atau penambahan jumlah padatan yang mengakibatkan berkurangnya jumlah air pada saat perlakuan. Pada penelitian ini perlakuan yang diberikan hanya pemberian energi dalam bentuk mantra, dimana secara susunan molekul, air tidak mengalami perubahan sehingga kadar air masih pada rata-rata 99,8\%. Penambahan kembang juga tidak mempengaruhi kadar air karena tidak banyak materi terlarut dalam yang tersuspensi pada air sehingga memberikan nilai kadar air tetap konstan selama perlakuan.

Kadar abu menunjukkan jumlah mineral pada bahan termasuk keberadaan logam-logam berat yang dinyatakan sebagai mineral terlarut. Hasil analisis kadar abu pada sampel menunjukkan bahwa total abu mengalami peningkatan yang sangat kecil. Kadar abu yang sedikit meningkat disebabkan kemungkinan ada beberapa mineral dari kembang yang terlarut pada sistem perendaman. Bahan kimia terutama mineral pada air bisa berasal dari kontaminasi selokan, limbah pabrik, limbah pertambangan, kebocoran septict tank, penggilangan, pengeboran, korosi perpipaan erosi deposit alami, serta hasil samping disinfeksi.

Terkait dengan mineral atau keberadaan logam terlarut pada sampel menunjukkan bahwa beberapa logam tidak terdeteksi yaitu $\mathrm{Fe}, \mathrm{As}, \mathrm{Zn}$ dan $\mathrm{Cd}$, sedangkan pada beberapa mineral terdeteksi dengan pengaruh terhadap perlakuan seperti Na. K. Mn, dengan kadar bervariasi ada yang mengalami peningkatan dan ada yang tidak dengan angka yang tidak jauh berbeda. Hasil analisis mineral menunjukkan bawa air dari sumber mata air terdeteksi logam berat $\mathrm{Pb}$ dari 0,25 menjadi $0.43 \mathrm{mg} / \mathrm{L}$ dengan persayaratan $0.05 \mathrm{mg} / \mathrm{L}$, sehingga bila ditinjau dari persyaratan mutu air minum terhadap kadar $\mathrm{Pb}$ pada sampel tidak memenuhi persyaratan dengan angka yang hampir 10 kalilipat dari standar maksimum $\mathrm{Pb}$ pada air sebagai sumber air minum. Serta terdapat beberapa mineral yang diperlukan oleh tubuh untuk kesimbangan cairan elektrolit seperti $\mathrm{K}$ dan $\mathrm{Na}$, dengan kadar yang berbeda pada perlakuan dimana $\mathrm{Na}$ pada kontrol mengalami penurunan sedikit pada perlakuan dan $\mathrm{K}$ mengalami peningkatan konsentrasi yang kemungkinan disebabkan oleh kembang yang ditambahkan pada perlakuan. 
Nitrogen adalah unsur yang umumnya terdapat pada sampel yang mengandung protein atau asam-asam amino, dan keberadaannya dalam air umumnya terikat sebagai nitrat $\left(\mathrm{NO}_{3}\right)$ yang merupakan ion anorganik alami, sebagai bagian dari siklus nitrogen. Aktivitas mikroba di tanah dan air menguraikan sampah yang mengandung nitrogen organik membentuk amonia, kemudian dioksidasi menjadi nitrit atau nitrat. Nitrat sebagai senyawa yang paling sering ditemukan di dalam air bawah tanah atau air yang terdapat di permukaan. Pencemaran akibat pupuk nitrogen termasuk amonia akan meningkatkan kadar nitrat dalam air. Senyawa yang mengandung nitrat dalam tanah akan mudah larut dan bermigrasi dengan air bawah tanah. Batas normal nitrat pada air bersih $50 \mathrm{mg} / \mathrm{L}$ dan pada air minum $10 \mathrm{mg} / \mathrm{L}$ (Permenkes No 416/1990). Kadar total nitrogen pada air $6,8 \mathrm{mg} / \mathrm{L}$ pada kontrol dan menurun menjadi $5,6 \mathrm{mg} / \mathrm{L}$ pada perlakuan pemberian mantra dan penambahan kembang.

Perlakuan terhadap air kelebutan pakerisan yang diberikan mantra doa dan kembang dalam aspek ilmu pasti terjadi pelarutan senyawa-senyawa aktif yang memiliki sifat polar, disamping itu doa atau mantra merupakan energi sehingga membantu proses ekstraksi bahan aktif secara natural tanpa ada pengaruh gerakan mekanik/ fisik terhadap sampel ekstraksi air yang dilakukan, sehingga mampu melarutkan senyawa bioaktif, salah satunya adalah flavonoid. Kelompok senyawa flavonoid memiliki peran sebagai senyawa penangkap radikal bebas, mampu menghilangkan pengaruh radikal dan sebagai antioksidan. Flavonoid merupkan kelompok fenol terbesar di alam yang memiliki peran dan fungsi fisiologis tertentu terhadap kesehatan.

Hasil analisis senyawa flavonoid, total fenol dan antioksidan pada kelompok kontrol tidak menunjukkan adanya senyawa yang mempunyai komponen bioaktif tersebut, sedangkan pada perlakuan menunjukan senyawa terlarut pada air sehingga terdeteksinya senyawa bioaktif dan kemampuannya dalam menghambat radikal bebas DPPh $0,1 \mathrm{mM}(1: 1)$, seperti tanpak pada gambar yang menunjukkan bahwa apabila sampel mengandung flavonoid makan reaksi warna dengan $\mathrm{AlCl}_{3}$ akan membentuk warna kuning, dan sampel pada perlakuan menunjukkan ada senyawa yang terdeteksi sebagai flavonoid. Begitu pula dengan analisis fenol (Gambar 4) ini juga menujukkan dengan intesitas warna biru yang dihasilkan dari sampel. Tampak jelas sekali bahwa perlakuan dan kontrol memberikan hasil yang positif. Kedua senyawa ini merupakan kelompok senyawa yang berperan sebagai antioksidan.

Kamboja dan kenanga yang ditambahkan umumnya pada pembuatan air suci mengandung senyawa aktif seperti tanin, saponin, Alkaloid dan flavonoid. [7], dalam penelitiannya menyatakan bahwa alkaloid sebagai zat aktif sebagai obat dan aktivator kuat bagi sel imun yang menghancurkan bakteri, virus jamur dan sel kanker. Kadar flavonoid pada ekstrak bunga kamboja sudamala $225.08 \mathrm{mg} / 100 \mathrm{~g}$ [8] Flavonoid mampu mereduksi pengaruh radikal bebas melalui pemberian atom hidrogen pada radikal bebas [9]. Hasil penelitian [10] menunjukkan bahwa 94,67\% aktivitas antioksidan merupakan hasil kontribusi dari flavonoid, sedangkan 5,33 $\%$ yang lain berasal dari senyawa lain selain flavonoid seperti senyawa fenolik sederhana atau senyawa karoten, dimana senyawa-senyawa tersebut berpotensi dikembangkan sebagai sumber antioksidan alami, antibakteri, anti inflamasi, antihiperlipid, antidiabetes dan memiliki efek fisiologis lainnya.

\subsection{Karakteristik Mikrobiologi Sampel}

Air minum merupakan air yang melalui proses pengolahan atau tanpa pengolahan yang memenuhi persyaratan kesehatan dan langsung dapat diminum (Permenkes, 2010). Air permukaan sangat rendan terhadap cemaran mikroba, karena air merupakan media transportasi 
yang efektif bagi mikroba [11] cemaran mikroba merupkan faktor yang sangat penting dalam pengukuran kualitas air baik untuk air minum ataupun air bersih.

Hasil analisis sampel air kelebutan pakerisan baik perlakuan dan kontrol dapat diketahui bahwa berdasarkan standar mutu air minum maka jumlah bakteri total dan coliform pada sampel kontrol memenuhi persyaratan kualitas air minum di hari ke 0 dan ke-5, sedangkan pada perlakuan air diberi mantra dan kembang justru terjadi kontaminasi pada hari ke-5 pengamatan yang dibuktikan bahwa total bakteri melebihi batas persyaratan air minum yang secara kalkulasi jumlah bakteri masih belum memenuhi kriteria. Hal ini kemungkinan disebabkan oleh penambahan kembang menjadi salah satu faktor meningkatnya kontaminasi coliform dan total mikroba.

Coliform adalah bakterio gram negative, tidak membentuk spora dan dapat tumbuh atau berkembang pada suhu $37^{\circ} \mathrm{C}$. Coliform merupakan kelompok bakteri yang mempunyai karakteristik biokimia dan pertumbuhan yang berhubungan dengan kontaminasi faecal. Namun demikian terdeteksinya coliform pada air tidak berarti adanya kontaminasi faecal karena coliform juga terdapat pada air yang tidak terkontaminasi oleh faecal, seperti Klebsiela, Enterobacter dan Centro bacter. Adanya coliform mengindikasikan kebersihan dan integritas sitem distribusi serta potensi terbentuknya biofilm [12], dan pengujian coliform dipersayatkan setiap minggu sekali terhadap air minum.

\section{Hari 0}

\begin{tabular}{|c|c|c|c|c|c|c|c|}
\hline \multirow[t]{2}{*}{ No } & \multirow{2}{*}{$\begin{array}{c}\text { Parameter } \\
\text { Analisis }\end{array}$} & \multirow[t]{2}{*}{ Satuan } & \multicolumn{4}{|c|}{ AIR KLEBUTAN PAKERISAN } & \multirow{2}{*}{$\begin{array}{c}\text { Permenperind } \\
\text { 78/M- } \\
\text { IND/PER/11/ } \\
2016\end{array}$} \\
\hline & & & KONTROL & $\pm \mathrm{SD}$ & PERLAKUAN & $\pm \mathrm{SD}$ & \\
\hline 1 & $\begin{array}{l}\text { Total Mikroba/ } \\
\text { TPC (Total plate } \\
\text { count) }\end{array}$ & $\mathrm{CFU} / \mathrm{mL}$ & $\operatorname{ttd}$ & $\operatorname{ttd}$ & $\operatorname{ttd}$ & $\operatorname{ttd}$ & \\
\hline 2 & Coliform & MPN/100mL & $\mathrm{ttd}$ & ttd & $\operatorname{ttd}$ & $\mathrm{ttd}$ & 50 \\
\hline \multicolumn{8}{|c|}{ Hari ke-5 } \\
\hline \multirow[t]{2}{*}{ No } & Parameter & Satuan & \multicolumn{4}{|c|}{ AIR KLEBUTAN PAKERISAN } & Permenperin \\
\hline & Analisis & & KONTROL & $\pm \mathrm{SD}$ & PERLAKUAN & $\pm \mathrm{SD}$ & $\begin{array}{c}\mathrm{d} 78 / \mathrm{M}- \\
\mathrm{IND} / \mathrm{PER} / 11 \\
/ 2016\end{array}$ \\
\hline 1 & $\begin{array}{l}\text { Total Mikroba/ } \\
\text { TPC (Total plate } \\
\text { count) }\end{array}$ & $\mathrm{CFU} / \mathrm{mL}$ & 38 & 0,58 & $2,9 \times 10^{5}$ & 0,000 & \\
\hline 2 & Coliform & $\mathrm{AMP} / 100 \mathrm{~mL}$ & 36 & 0,0 & 1100 & 25,456 & 50 \\
\hline
\end{tabular}

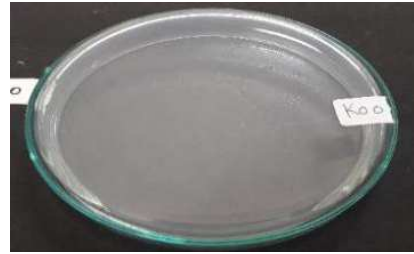

Kontrol hari ke-0

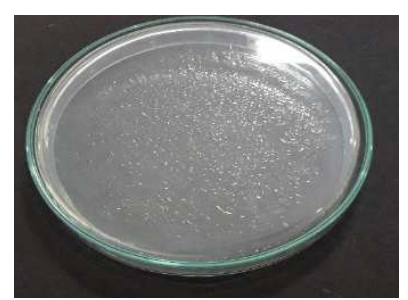

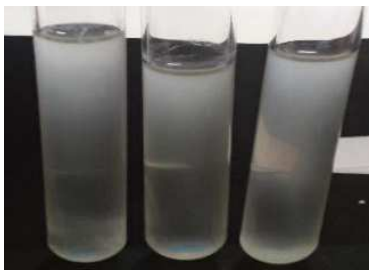

Kontrol hari ke-0

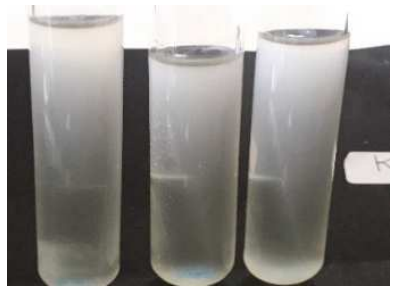


Perlakuan hari ke 0
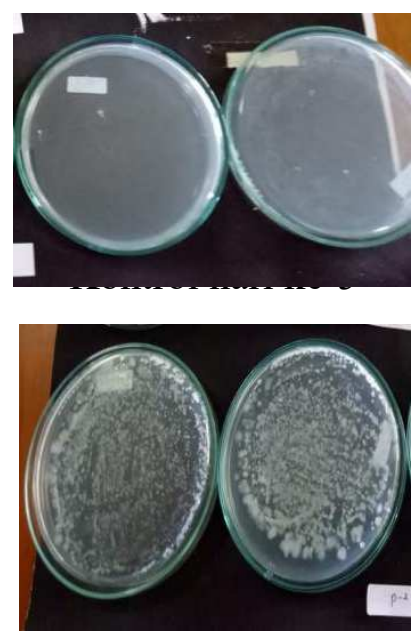

Total Mikroba
Perlakuan hari ke 0
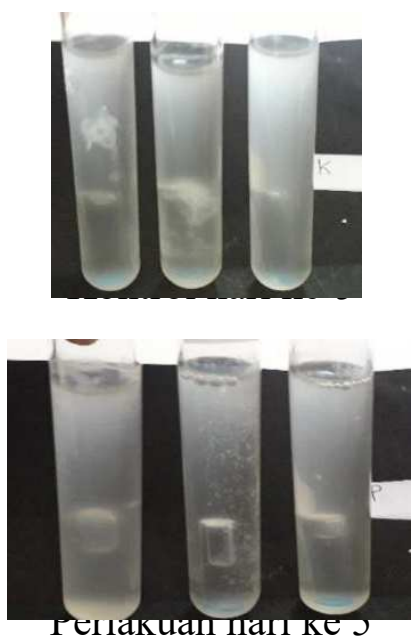

Coliform

\section{Kesimpulan}

Kualitas air secara fisika pada kontrol dan perlakuan memenuhi syarat air minum; berdasarkan parameter kimia diperoleh bahwa terdapat mineral logam berat $\mathrm{Pb}$ dengan kadar tinggi baik pada kontrol dan perlakuan; mutu air dari segi mikrobiologi menunjukan bahwa terjadi peningkatan jumlah coliform dan total bakteri yang menyebabkan kontaminasi pada saat perlakuan; perlakuan penambahan kembang dan mantra pada sampel air menyebakan air memiliki komponen sebagai antioksidan.

\section{References}

[1] M. . Soekarto, K. Atmodjo, Arti Air Penghidupan Dalam Masyarakat Jawa. Yogyakarta: Proyek Javanolog, 1982.

[2] I. B. Dharmika, Peradaban Air. Denpasar: Sakha Press, 2017.

[3] T. Ohta et al., "Separation and measurement of 129I and 127I in pre-nuclear-era marine algae with ultra-low 129I/127I isotopic ratios," Nucl. Instruments Methods Phys. Res. Sect. B Beam Interact. with Mater. Atoms, vol. 294, pp. 559-562, 2013.

[4] Y. Mahara et al., "Pore-water mobility: Distribution of $\delta 37 \mathrm{Cl}, 36 \mathrm{Cl} / \mathrm{Cl}, 129 \mathrm{I} / 127 \mathrm{I}$ and dissolved 4He concentration in the core drilled in the Mobara gas field, Japan," Nucl. Instruments Methods Phys. Res. Sect. B Beam Interact. with Mater. Atoms, vol. 294, pp. 597-601, 2013.

[5] T. Fujii, Y. Sato, H. Lin, H. Inomata, and T. Hashida, "Evaluation of CO2 sorption capacity of rocks using a gravimetric method for $\mathrm{CO} 2$ geological sequestration," Energy Procedia, vol. 1, no. 1, pp. 3723-3730, 2009. 
[6] X. L. Fu, D. Li, and X. F. Zhang, "Simulations of the three-dimensional total dissolved gas saturation downstream of spillways under unsteady conditions," J. Hydrodyn., vol. 22, no. 4, pp. 598-604, 2010.

[7] F. Olivia, S. Alam, and I. Hadibroto, Seluk beluk Food Suplemen. . . Jakarta: PT Gramedia, 2004.

[8] I. B. K. . Yoga, Analisis Senyawa Kimia Daun Kacapiring. Yogyakarta: Plantaxia, 2018.

[9] P. K. Wilmsen, D. S. Spada, and M. Salvador, "Antioxidant activity of the flavonoid hesperidin in chemical and biological systems,” J. Agric. Food Chem., vol. 53, no. 12, pp. 4757-4761, 2005.

[10] A. Rohman, S. Riyanto, and N. K. Hidayat, "Aktivitas Antioksidan, Kandungan Fenolik Total , ( Morinda citrifolia L )," Agritech, vol. 27, no. 4, pp. 147-151, 2007.

[11] C. Levantesi, L. Bonadonna, R. Briancesco, E. Grohmann, S. Toze, and V. Tandoi, "Salmonella in surface and drinking water: Occurrence and water-mediated transmission," Food Res. Int., vol. 45, no. 2, pp. 587-602, 2012.

[12] G. . Medema et al., "Assessing microbial safety of drinking water: Improving approaches and methods," Assess. Microb. Saf. Drink. Water Improv. Approaches Methods, vol. 9789264099, pp. $1-295,2003$.

[13] Kementerian Perindustrian R.I. (2016). Peraturan Menteri Perindustrian R.I. Nomor 78/MIND/PER/10/2016. Jakarta

[14] Menteri Kesehatan R.I. (2010). Keputusan menteri Kesehatan R.I. Nomor 492/ MENKES/PER/IV/2010. Departemen Kesehatan Jakarta. 